\title{
ИНТЕРПРЕТАЦИЯ ТВОРЧЕСТВА В КУЛЬТУРНО-ИСТОРИЧЕСКОЙ ТРАНСФОРМАЦИИ ${ }^{1}$
}

\section{INTERPRETATION OF CREATIVITY IN CULTURAL AND HISTORICAL TRANSFORMATION}

\section{Raitina}

Summary: The article deals with the peculiarities of understanding creativity in the horizon of cultural and historical transformation. It is noted that the interpretation of the interpretation of creativity is associated with the constitution of a person's cultural world, which determines his existential space. An analysis of the philosophical systems of thinkers belonging to a certain historical era reveals a connection with their personal meanings and values, which are directly determined by the socio-cultural context. An overview of the concepts of creativity from antiquity to modern philosophical tendencies is given. It is concluded that the nature of creativity, creative processes is set by the corresponding turn in philosophy and can be investigated on the basis of an interdisciplinary approach.

Keywords: creativity, man, culture, society, values.

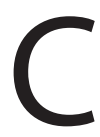

овременная культурная ситуация обусловливает необходимость развитие творческого потенциала человека, креативных способностей, позволяющих соответствовать новым реалиям мира. Соответственно постижение творчества как одного из культурных оснований действительности является актуальным и было заложено на самых ранних этапах культурно-исторического развития общества. Исследованием творчества с позиции его природы и сущности занимались многие авторы, начиная с Платона, а далее Гегель, А. Шопенгауэр, Ф. Ницше, А. Бергсон, Н.А. Бердяев, Г.С. Батищев, А.Ф. Лосев, О.Б. Афанасьев. Общефилософским вопросам творчества и креативности посвящены работы А.И. Субетто, В.Н. Николко, М.А. Кузнецовой, В.А. Лекторского, И.А. Бесковой, Д.Н. Боровинской, А.И. Столетова и др.

Социокультурная трансформация трактовки творчества связана с конституированием культурного мира человека, определяющего его экзистенциальное пространство, что соотносится с личностными смыслами и ценностями эпохи и детерминировано культурно-историческим контекстом.
Раитина Маргарита Юрьевна

К.ф.н., дочент, Томский государственный университет систем управления и радиоэлектроники raitina@mail.ru

Аннотация: В статье рассмотрены особенности понимания творчества в горизонте культурно-исторической трансформации. Отмечено, что интерпретация трактовки творчества связана с конституированием культурного мира человека, определяющим его экзистенциальное пространство. Анализ философских систем мыслителей, принадлежащих к определенной исторической эпохе, обнаруживает связь с их личностными смыслами и ценностями, которые напрямую детерминированы социокультурным контекстом. Приведен обзор концепций творчества от античности до современных философских тенденций. Сделан вывод, что природа творчества, творческих процессов задана соответствующим поворотом в философии и может быть исследована на основе междисциплинарного подхода.

Ключевые слова: творчество, человек, культура, общество, ценности.

Так, в контексте античной социокультурной реальности творчество начинает рассматриваться как процесс создания ранее не существующего, усматривая стремление человека к совершенству и созиданию. Наиболее отчетливо проблема творчества была поставлена Платоном. Согласно Платону, творчество представляет собой искусство созидания, существуя в двух ипостасях. Во-первых, в качестве сущностного аспекта эйдоса, или первообраза, модели творения. Во-вторых, в виде творческого акта, в процессе которого план творения превращается в сотворенное. Для названия последнего Платон и употребляет понятия демиурга, творца, создателя [8].

Несколько иную интерпретацию творчества можно обнаружить в учении Аристотеля. Аристотель рассматривает понятие «перводвигатель», как принцип творчества, усматривая в нем субстанцию, а следовательно, источник изменения и появления нового, в то время как человеческий ум потенциален в становлении всего [1]. Последнее определяет творчество как атрибут человеческого бытия.

С точки зрения западноевропейской средневековой

Работа выполнена в рамках базовой части государственного задания «Наука», FEWM-2020-0036. 
философии, которая исходит из доминантной категории - понятия Бога, творчество понимается как имманентное бытию (Августин, Ф. Аквинский). В свою очередь дух, проявленный в человеке, есть его высшая сущностная основа, сообщающая возможность творчества человеку. Таким образом, Бог становится объективностью, определяющей и направление, и содержание творческой деятельности человека.

Социокультурная аура эпохи Возрождения, а далее Нового времени задает совершенно новые реалии, направленные на возвеличивание человека, его потенциала и творческих возможностей, передавая от Бога к человеку способность творить и воплощать творения в реальность. Рационалистическая философская традиция определяет творчество, прежде всего, с позиции разума человека и его разумной деятельности, нацеленной на изменение мира силой разума, равного по мощи Разуму Бога. Начиная с Р. Декарта, cogito постулируется в качестве основы бытия, что задает возможность творчества [6]. При этом реконструкции творчества, как деятельности «чистого разума», напрямую связаны с успехами в естествознании, признанием апогея научного познания и получением наукой самостоятельного статуса.

Философия рубежа XIX-XX веков развивалась под воздействием противоречивых культурно-исторических событий, радикального пересмотра научных оснований, что, по сути, обозначило конфликт разумного и неразумного в деятельности человека. Как следствие в культуре наряду с рациональным пониманием мира актуализировались тенденции иррационализма, когда на место разума ставились иные проявления духовного (воля, интуиция, бессознательное) и акцент в понимании творчества был смещен в область иррационалистических интерпретаций. Так, Н. Бердяев считает основным смыслом творчества «самораскрытие сил бытия», творчество - это одно из основных выражений свободы [2].

Решение проблем творчества через призму человеческой иррациональности, а именно такого ее глубинного слоя как бессознательное, объединяет многие концепции и концептуализации, которые в качестве исходного методологического принципа используют то или иное положение классиков фрейдизма, неофрейдизма. Д. Деннет исходным посылом творчества считал инстинкт познания истины, инстинкт, который вторичен по отношению к глубинной жажде выживания [7]. Ему вторит С. Гусев, отмечающий, что творчество обусловлено инстинктивной реакцией на вызовы среды, которые и генерируют творческое созидание способов и механизмов адаптации [5].

Вторая половина XX века привносит смену исследовательской парадигмы и актуализирует новые тенденции в рассмотрении творчества (постмодернизм, синергетика, универсальный эволюционизм, прагматизм и т.п.). Как следствие, формирование человека экономического, во многом нацеленного на утилитаризм, но в то же время способного к многозадачности в быстро меняющемся мире, диктует необходимость развития творческих способностей [3, 4]. Так, Р. Флорида вводит понятие креативного класса как самого влиятельного в современном обществе [9]. Данная интенция генерируется представлением о современной эпохе как веке проектной культуры, что находит отражение в концептуализациях инновационного университета, где отличительной чертой образования становится обучение проектному мышлению. Последнее достигается, в частности, и путем внедрения в процесс обучения проектноориентированных образовательных технологий. Тем самым подчеркивается, что специалист должен обладать инновационным мышлением, интенцией на творческое созидание, а это достигается за счет обучения проектированию, понимания характера проектных процессов как творческих по своей сущности.

Вышеобозначенный теоретический обзор позволяет сделать вывод о том, что представление о творчестве менялось в соответствии со спецификой соответствующего поворота в философии (антропологический, коммуникативный, прагматический и др.), а также культурно-историческим контекстом эпохи. Целостный анализ творчества, позволяющий отразить его современное видение, возможен на основе методологии комплексности и междисциплинарности.

Таким образом, заключим, что осмысление творчества сегодня возможно, во-первых, как характеристики, имманентно присущей человеку, человеческой деятельности; во-вторых, как обобщенной проявленности универсальной креативности бытия, которая обеспечивает самообновление и развитие мира сущего и культуры в целом.

\section{ЛИТЕРАТУРА}

1. Аристотель. Собр. соч.: в 4 т. - М.: Мысль, 1976-1984.

2. Бердяев Н. Смысл творчества / Бердяев Н.А. Философия творчества, культуры и искусства: в 2-х т. Т. 1. - М.: Искусство, 1994. С. 137.

3. Боровинская Д.Н. Проблема креативности в образовательной перспективе: монография / Д.Н. Боровинская. - Томск: Издательский дом Том. гос. ун-та, 2019. -220 c. 
4. Боровинская Д.Н. Экономические и культурные основания креативности // Вестн. Том. гос. ун-та. - 2014. - №388. D0I: 10.17223/15617793/388/8

5. Гусев С.С. Смысл возможного. - СПб.: Алетейя, 2002. - 384 с.

6. Декарт, Р. Избранные произведения. - М.: Госполитиздат, 1950. - 712 с.

7. Деннет Д. Постмодернизм и истина текст // Вопросы философии. - 2001. - № 8. - С. 93-100.

8. Раитина М.Ю. Реконструирование творчества в контексте античного объективизма // Вестник Костромского государственного университета им. Н.А. Некрасова. - 2014. - T. 20, № 7. C. 150.

9. Florida R. The Rise of Creative Class. - Hachette UK, 2019. - 512 p.

( Р Раитина Маргарита Юрьевна (raitina@mail.ru).

Журнал «Современная наука: актуальные проблемы теории и практики»

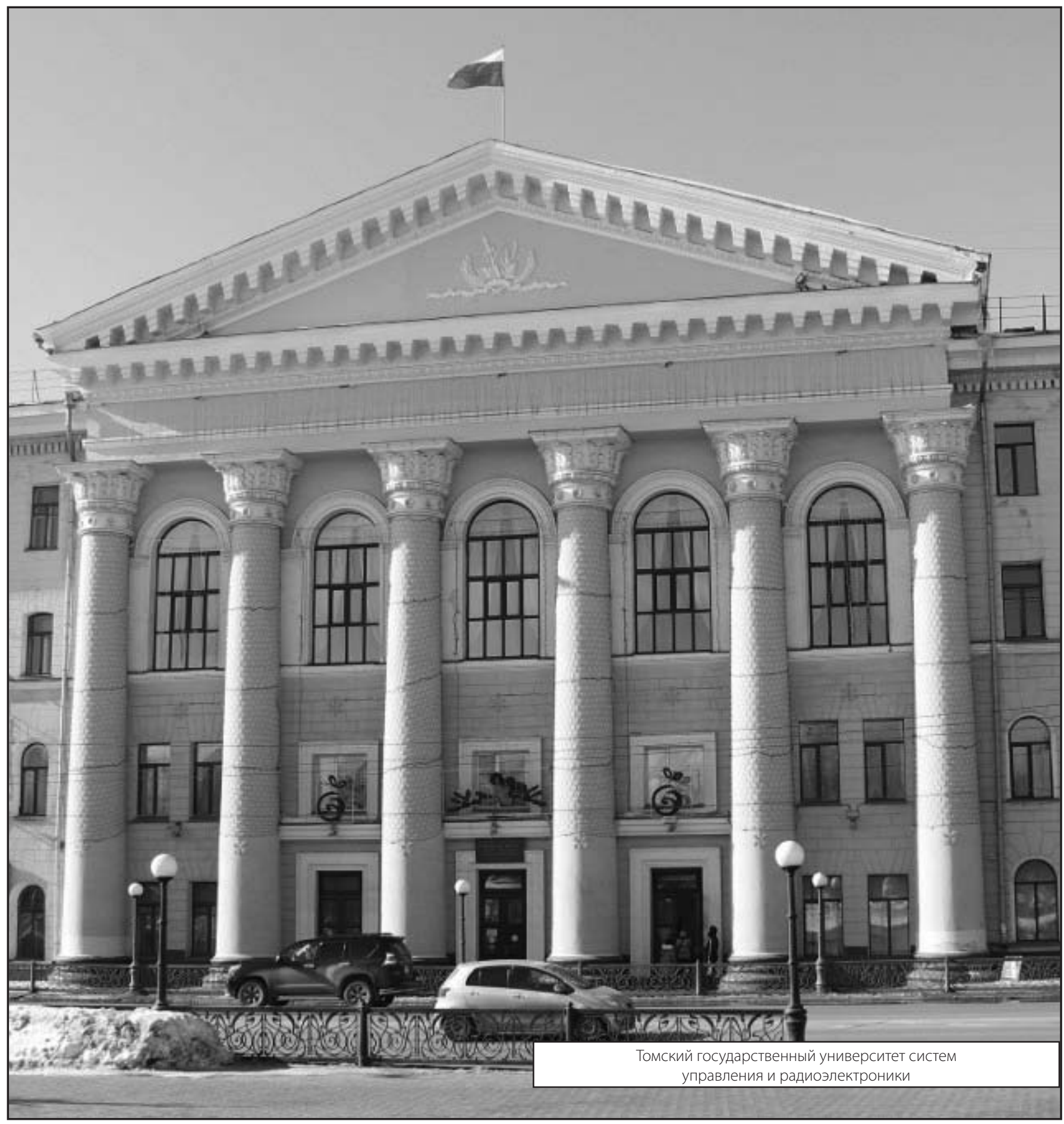

